\title{
Quality of fresh plant residue affects sequestration of residue derived organic material by humic acid
}

\section{Jumana Al-Mallahi *, Ragheb Tahhan, Sa'eb Khresat}

Department of Natural Resources and Environment, Faculty of Agriculture, Jordan University of Science and Technology, Irbid, Jordan

\section{Article Info}

Received : 18.01.2020

Accepted : 20.04.2020

\begin{abstract}
Increasing the retention and sequestration of plant residue carbon in agricultural soils by incorporating humic acid is the main focus of this study. This study aims to examine the effect of humic acid addition on the decomposition of plant residues of varying degrees of lability. Respiration experiments were conducted to estimate the ability of humic acid to protect plant derived organic compounds from decomposition. Humic acid reduced mineralization from all added residues and this protection effect followed the lability of the residues: vetch> wheat> oak. This could be attributed to the chemical interaction between different plant-derived organic compounds and the humic acid. Lysine was strongly adsorbed to humic acid and mineralization was reduced by $23 \%$ as a result of the strong electrostatic interaction. Applying humic acid with vetch reduced all microbial indices as a result of less substrate availability for miroorganisms. On the other hand, applying humic acid with wheat might have simulated the synthesis of extracellular enzymes and the co-metabolism of humic acid (brimming effect), resulting in an enhanced microbial structure toward a higher fungal population. This study suggests: (1) Applying humic acid to ecosystems that receive labile residues (such as vetch) to reduce mineralization and enhance carbon sequestration (2) Applying less labile residues (such as wheat) in combination with humic acid to recover degraded soils and enhance carbon sequestration.
\end{abstract}

Keywords: Carbon sequestration, enzymatic activity, humic acid, plant residue quality.

(c) 2020 Federation of Eurasian Soil Science Societies. All rights reserved

\section{Introduction}

Sequestration of carbon in soils depends on the amount of carbon that is conserved during the decomposition process as plant residues are added to soil. Residue carbon inputs are the major source of Soil Organic Matter (SOM), thus higher residue carbon retention influence both soil structure (Pituello et al., 2016) and fertility. In addition to its importance in agronomy, higher residue carbon retention in soil is beneficial from an environmental point of view, mainly for the mitigation of greenhouse gases (ESA, 2000). Wang et al. (2017) pointed out that about $55 \%$ to $70 \%$ of residue $\mathrm{C}$ can be mineralized and released as $\mathrm{CO} 2$ within one year after addition. Therefore, residue management practices should aim to enhance long-term SOC sequestration, thus minimizing the adverse impact on global climate change (Mahmoodabadi and Heydarpour, 2014).

Physical and chemical protection of organic materials against mineralization is a crucial way to enhance the potential of soil as a sink of carbon. Organic materials can be physically protected in the interior of soil aggregates, where microorganisms and their enzymes have limited access and where oxygen concentration may also be low (Rovira and Vallejo, 2003). In addition, organic material can be chemically protected by adsorption to mineral surfaces (Rasmussen et al., 2006). Recently, some studies showed the ability of stable organic materials to sequester carbon of easily degradable materials. Biochar is the by-product of the pyrolysis of organic wastes and is regarded as a stable carbon pool. Jien et al. (2015) emphasized on the role
* Jumana Al-Mallahi
Ragheb Tahhan
Sa'eb Khresat
m_jumana@yahoo.com tahhan@just.edu.jo skhresat@just.edu.jo

0000-0003-1821-0199 0000-0002-0577-6495 0000-0003-4303-0384
(Corresponding author) 
of biochars in carbon sequestration. Melas et al. (2017) also showed that labile organic materials (such as glucose) can be protected against mineralization by sorption on biochar amended soils. Tian et al. (2015) showed that greater crop residue carbon was retained in biosolids-amended soil (32.5\% of total crop residue carbon) compared to unamended soil (11.8\%). Spaccini et al., (2002) showed that applying humic acids to soil could exert a protection effect of organic carbon by reducing mineralization of the relatively labile aliphatic alcohol such as 13C-2-decanol.

Testing the potential of humic acid to retain plant residue carbon in agricultural soils is the main focus of this study. Previous studies that tested the sequestration ability of humic acid are limited (Piccolo et al., 1999; Spaccini et al., 2002; Piccolo et al., 2004). The effect of plant residue quality and different plant derived organic molecules on the interaction with humic acid needs further investigation. Therefore, this study aims to examine the effect of humic acid addition on the decomposition and stability of plant residues with varying degrees of lability. Soil with a relatively low soil organic carbon content was used. Humic acid was applied with three different plant residues having varying degrees of lability (vetch, wheat and oak). Soil respiration experiments as well as different microbial quality indicators were performed to assess the effect of humic acid addition on carbon mineralization and sequestration. We hypothesized that plant residue quality and composition, mainly the soluble fraction and the proportion of different low molecular weight organic substances (LMWOS) might affect the interaction between plant residue and humic acid. Understanding the interaction between different plant residues and humic acid may give us some insight for the efficient application of humic acid to promote residue carbon sequestration in agricultural soils.

\section{Material and Methods}

\section{Soil}

Surface $(0-20 \mathrm{~cm})$ representative composite soil sample was collected from Ajloun area in Jordan. The sample was taken from a land that was forest in the past, but the forest was cleared and the land was converted to cultivation. The sample was brought to the laboratory and air dried. For physical and chemical analysis, portion of the soil was sieved through $2 \mathrm{~mm}$ mesh size sieve. The remaining was passed through a $6.3 \mathrm{~mm}$ sieve in order to be used for biological analysis as well as for respiration and incubation experiments. The soil has a relatively low carbon content of $1.32 \%$. A summary of the soil characteristics is shown in Table 1.

Table 1. Physical, chemical and biological characteristics of the soil used in the study

\begin{tabular}{|c|c|c|c|}
\hline Soil property & \multicolumn{3}{|c|}{ Value } \\
\hline Moisture (\%) & \multicolumn{3}{|c|}{15.8} \\
\hline Total soil organic carbon $\%$ & 1.32 & \pm & 0.05 \\
\hline Total nitrogen $\%$ & 0.13 & \pm & 0.01 \\
\hline Soil pH & 7.93 & \pm & 0.20 \\
\hline Electrical conductivity & 192.50 & \pm & 0.05 \\
\hline Soil Texture & \multicolumn{3}{|c|}{ Clay } \\
\hline Microbial biomass ( $\mu \mathrm{g} \mathrm{C} \mathrm{g}^{-1}$ soil) & 621.00 & \pm & 8.65 \\
\hline Basal respiration ( $\mu \mathrm{g} \mathrm{CO}_{2} \mathrm{~g}^{-1}$ soil $\mathrm{hr}^{-1}$ ) & 0.57 & \pm & 0.13 \\
\hline$\beta$ - glucosidase activity ( $\mu \mathrm{g} \mathrm{pNP} \mathrm{g}^{-1}$ soil $\mathrm{hr}^{-1}$ ) & 238.17 & \pm & 0.01 \\
\hline Dehydrogenase activity ( $\mu \mathrm{g}^{\mathrm{TPF}} \mathrm{g}^{-1}$ soil $\mathrm{hr}^{-1}$ ) & 5.24 & \pm & 0.30 \\
\hline$\beta$ - glucosaminidase activity ( $\mu \mathrm{g} \mathrm{pNP}^{-1}$ soil $\mathrm{hr}^{-1}$ ) & 15.50 & \pm & 0.89 \\
\hline
\end{tabular}

* Values of standard deviations are a mean of triplicates

\section{Soil additives}

Three plant residues were selected for this study area; stem and leaf portions of vetch (Vicia sativa) and wheat (Triticum aestivum), in addition to oak (Quercus Calliprinos) leaves. Collected plant materials were dried at $60 \mathrm{C}$ o and ground to pass through $1 \mathrm{~mm}$ sieve. These plant residues were selected according to their lability and affinity to degradation. This study requires the use of plant residues with varying degrees of lability. Oak is a tree litter with higher degree of recalcitrance compared to vetch and wheat. Vetch has lower lignin content and $\mathrm{C} / \mathrm{N}$ ratio thus is the most labile plant residue in this study (Baumann et al., 2009). In addition to the plant residues, the following materials were used to treat soil samples: Glutamine, Lysine, glucose and octanol.

K-humate, Humic acid material isolated from leonardite, was brought from Rehana Agricultural Middle East Company, Jordan. This material was $90 \%$ pure; humic acid consists $90 \%$ of it. Throughout this study we will refer to this material as humic acid (HA). The characteristics of the humic acid used in this study are illustrated in Table 2. 
Table 2. Characteristics of the humic acid used in this study

\begin{tabular}{lr} 
Property & Value \\
\hline Purity (percentage of humic acid in the organic material) (\%) & 90 \\
$\mathrm{C}, \%$ & 71.05 \\
$\mathrm{~K}, \%$ as $\mathrm{K}_{2} \mathrm{O}$ & 12.00 \\
$\mathrm{~N}, \%$ & 0.72 \\
$\mathrm{Si}, \%$ & 0.89 \\
$\mathrm{Ca} \%$ & 0.78 \\
$\mathrm{Mg}, \%$ & 0.45 \\
$\mathrm{Na}, \%$ & 1.45 \\
Fe, $\%$ & 3.00 \\
Boron (ppm) & 29.00 \\
Specific gravity & 0.82 \\
pH (ambient temperature) & $8-9$ \\
CEC, mmole/g & 3.22 \\
Acidic functional groups, mmole/g/ml & 5.03
\end{tabular}

\section{Respiration experiments}

A preliminary experiment was done to determine the appropriate amount of humic acid to be used. Air dried soil (equivalent to $50 \mathrm{~g}$ oven dry weight) was incubated, in duplicate, with $2 \%$ of vetch residue and different rates of humic acid; $5 \mathrm{~g}, 10 \mathrm{~g}$ and $15 \mathrm{~g}$ of humic acid per $50 \mathrm{~g}$ of (oven dried) soil equivalent to $10 \%, 20 \%$ and $30 \%$ respectively. Microcosms were incubated for 13 days at $25{ }^{\circ} \mathrm{C}$. Soil moisture was adjusted and maintained at $60 \%$ of water holding capacity (WHC).

To quantify the protection provided by humic acid for different plant residues, a respiration experiment was performed by amending 50 g soil with $2 \%$ of different plant residues, namely; vetch, wheat or oak in addition to $20 \%$ of humic acid. Treatments were: i. Control: soil alone ii. HA: humic acid+soil iii. Vetch: soil+vetch iv. Vetch+HA: soil+ vetch+ humic acid v. Wheat: soil+ wheat vi. Wheat+HA: soil+ wheat+ humic acid vii. Oak: soil+ oak viii. Oak+HA: soil+ oak+ humic acid. Treatments were conducted in triplicates.

Another respiration experiment was performed to study the protection of humic acid to individual plantderived low molecular weight organic substances (LMWOS); lysine, glutamine, glucose and octanol. In triplicate, $50 \mathrm{~g}$ oven dry weight of soil was treated with $0.2 \mathrm{~g}(0.4 \%)$ substrate with or without $20 \%$ of humic acid.

In all respiration experiments evolved $\mathrm{CO}_{2}$ was trapped by a $1 \mathrm{~N} \mathrm{NaOH}$ solution and measured periodically by back titrating the residual $\mathrm{NaOH}$ with $0.1 \mathrm{~N} \mathrm{HCl}$.

\section{Incubation Experiment}

Wheat and vetch residues were used in this study. $2 \%$ of each residue was applied to $300 \mathrm{~g}$ of soil, either alone or in combination with humic acid. Incubations were performed in jars $(1.5 \mathrm{~L})$. The jars were opened daily to facilitate air circulation. The jars were weighted periodically; water was added to maintain soil moisture at $60 \%$ of WHC to keep moisture constant. Treatments in this study were: i. Control: soil ii. Wheat: soil + wheat iii. Vetch: soil + vetch iv. Vetch+ HA: soil + vetch+ HA v. Wheat+ HA: soil + wheat+ HA.

About $30 \mathrm{~g}$ moist soil sample was taken from each jar at the intervals $0,3,8,16,23$ and 30 days of incubation for enzymatic activity assays. At the end of the incubation period, fungal respiration, bacterial respiration and microbial biomass were evaluated by conducting substrate induced respiration (SIR) as described below.

\section{Analytical methods}

\section{Chemical and physical analysis}

Water content was measured according to Walter (1986). Soil pH was determined in 1:1 soil: water extract (Thomas, 1996). Organic matter was estimated by measuring organic carbon, using Walkley Black method (Nelson and Sommers, 1996). The hydrometer method was used for determining soil texture (Gee and Bauder, 1986). Kjeldal method (Bremner, 1996) was used to measure total nitrogen.

\section{Biological analysis}

Microbial biomass carbon (MBC): $\mathrm{MBC}$ was determined by fumigation extraction method (Brookes and Joergenseu, 2005). Briefly, $10 \mathrm{~g}$ soil was extracted with $50 \mathrm{ml} 0.5 \mathrm{M} \mathrm{K}_{2} \mathrm{SO}_{4}$ after being fumigated for 5 days with ethanol free chloroform. MBC was calculated as follows:

$$
\mathrm{MBC}\left(\mathrm{mg} \mathrm{C} \mathrm{g}{ }^{-1} \text { soil) }=\mathrm{EC} / \mathrm{K}_{\mathrm{EC}}\right.
$$

Where EC is the difference in organic carbon extracted from fumigated soil and the non- fumigated soil and $\mathrm{K}_{\mathrm{EC}}=0.38$ (Moscatelli et al., 2007). 
Soil basal respiration: A respiration experiment was conducted and the value of carbon dioxide production rate was recorded after 8 days when the respiration activity reached a steady state.

Enzymatic activities: $\beta$-glucosidase activity was evaluated by the method described by Tabatabai (1994) using $0.05 \mathrm{M}$ pNP $\beta$-D- glucopyranoside as a substrate. NAGase activity was assayed using $0.065 \mathrm{M}$ pNP-N acetyl- $\beta$-D- glucosaminidine (Parham and Deng, 2000). The intensity of the yellow color was measured calorimetrically with a spectrophotometer at $405 \mathrm{~nm}$. Dehydrogenase was assayed by reducing 2.3.5Triphenyltetrazollium chloride (TTC) to Triphenyl formazan (TPF). The absorbance of TPF was measured calorimetrically at $485 \mathrm{~nm}$ (Tabatabai, 1994).

Substrate induced respiration (SIR): SIR was done according to Lin and Brookes (1999). Preliminary experiments were done to determine the optimal concentration of glucose and the optimal incubation period. $15 \mathrm{~g}$ soil (oven dry weight bases) was amended with $4 \mathrm{mg} \mathrm{g}^{-1}$ glucose and the rate of respiration was measured after 18 hours.

Fungal and bacterial respiration: Fungal and bacterial respiration were done following the procedure described by Bailey et al. (2002). Briefly, preliminary Tests were done to determine the amounts of antibiotics required to maximally suppress respiration. Afterwards, SIR with selective inhibition was conducted with the following three treatments: (A) No addition of antibiotics (B) Soil treated with $8 \mathrm{mg} \mathrm{g}^{-1}$ cycloheximide and (C) Soil treated with $8 \mathrm{mg} \mathrm{g}^{-1}$ streptomycine. This experiment was done in duplicate.

\section{Statistical analysis}

A one-way ANOVA was carried out to look at the effect of HA addition on different treatments. Significant $(\mathrm{P}=0.01)$ differences between treatments were Identified.

\section{Results}

\section{The effect of humic acid addition on respiration and carbon mineralization}

Less carbon was mineralized as humic acid rate increased. For example, the treatment of $30 \%$ of humic acid released $1452.80 \mathrm{mg} \mathrm{C} \mathrm{kg}^{-1}$ soil, while $10 \%$ resulted in $2544.80 \mathrm{mg} \mathrm{C} \mathrm{kg}^{-1}$ soil (Figure 1). The relationship between humic acid amount and total mineralized carbon within 13 days was linear $\left(r^{2}=0.99\right)$ and quantitative within the tested range of humic acid. Accordingly, $20 \%$ was chosen to conduct the other experiments in order to facilitate the recognition of the effect of humic acid application in the experimental level that we performed. In real situation, this high concentration will not be applied at once; however, continuous additions of humic acids might result in the accumulation of high concentration of humic acid.

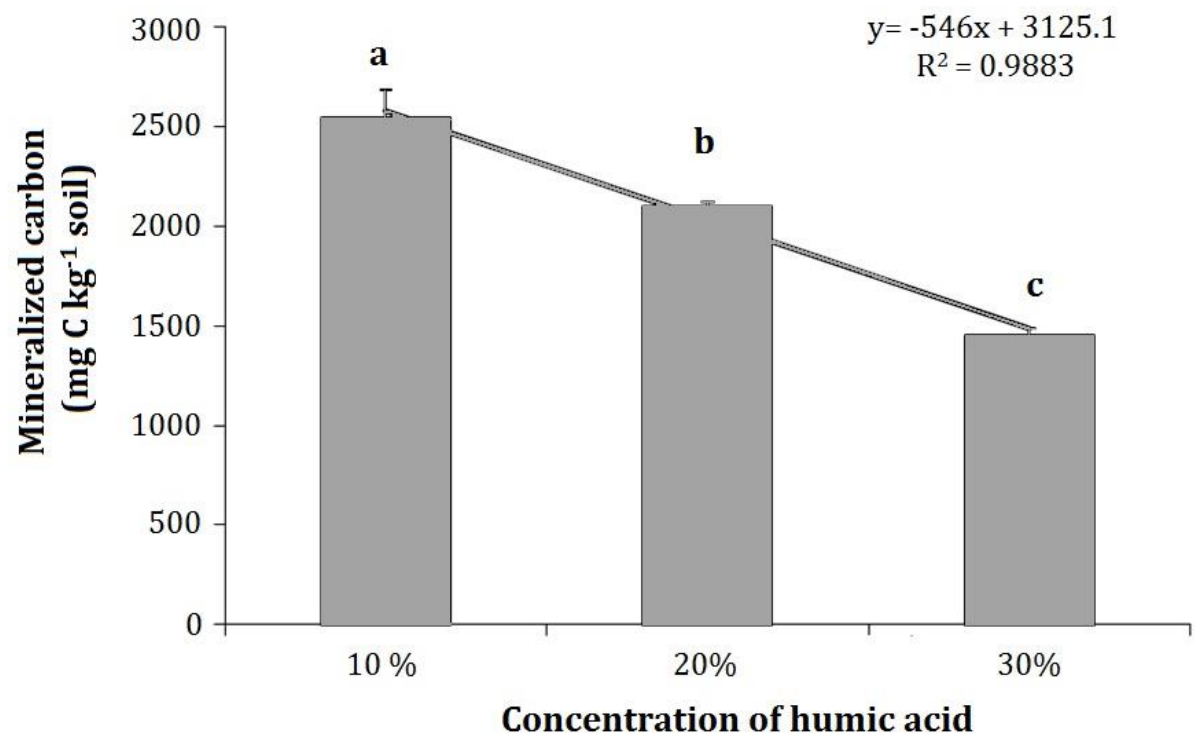

Figure 1. Total carbon mineralization over 13 days of incubation of $2 \%$ vetch residue with different concentrations of humic acid. Error bars are standard deviations from means of duplicate. No significant difference between treatments with same letter $(\mathrm{P}=0.01)$

Figure 2a shows the pattern of carbon mineralization from vetch, wheat and oak. Initially humic acid significantly $(\mathrm{P}=0.01$, day 3$)$ reduced the amount of carbon mineralized from all the plant residues. The effect of humic acid in reducing mineralization then decreased with time. Later on, humic acid caused higher mineralization from the wheat and oak treatments. Humic acid seemed to be more effective in reducing decomposition of vetch litters. 
Cumulative carbon mineralization from soil amended with either $0.4 \%$ of lysine, glutamine or glucose is shown in Figure 3. Applying humic acid significantly reduced carbon mineralization from lysine throughout the incubation period; it was significantly ( $\mathrm{P}=0.01$, day 13) reduced from $1210.09 \mathrm{mg} \mathrm{C}^{-1} \mathrm{~kg}^{-1} 930.26 \mathrm{mg} \mathrm{C}$ $\mathrm{kg}^{-1}$. For both glutamine and glucose, humic acid significantly $(\mathrm{P}=0.01)$ reduced mineralization for the first three days, later on this effect diminished. Among the LMWOS in our study, the effect of humic acid protection was the least for octanol, which is the most hydrophobic (least soluble) compound in this study (data not shown).
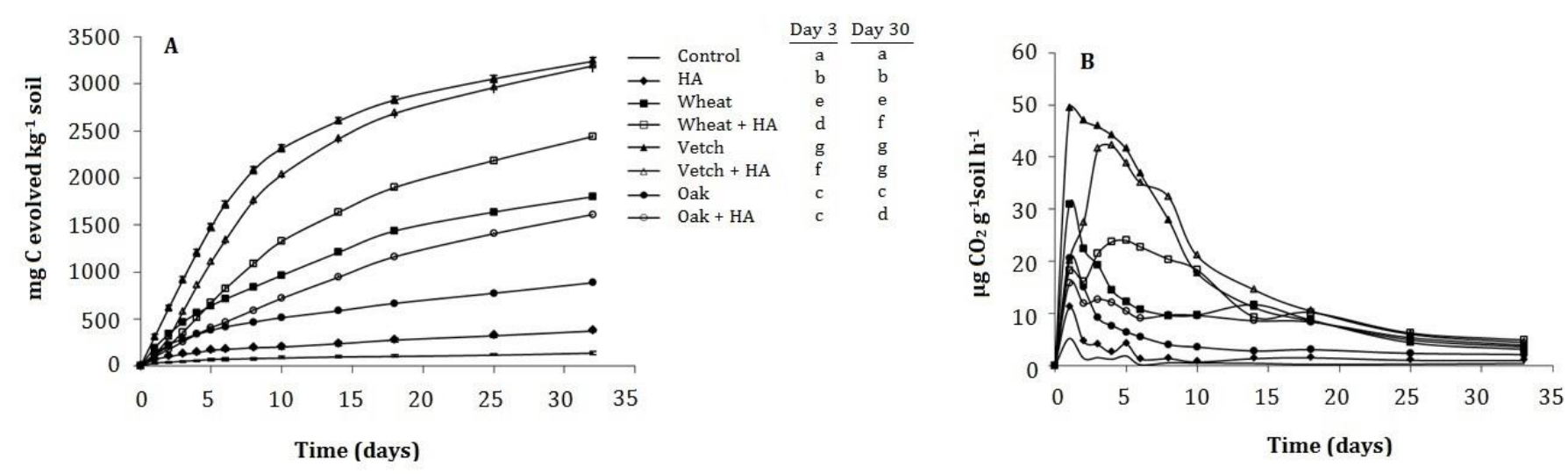

Figure 2. Respiration experiment of $2 \%$ of different plant residues with or without $20 \%$ humic acid a) Cumulative carbon $\mathrm{C}-\mathrm{CO}_{2}$ evolved (mg C kg-1 soil) and b) Rates of $\mathrm{CO}_{2}-\mathrm{C}$ evolution ( $\mu \mathrm{g} \mathrm{CO}_{2} \mathrm{~g}^{-1} \mathrm{soil} \mathrm{h}^{-1}$ ). Error bars are standard deviations from means of duplicate. No significant difference between treatments with same letter within the same day $(\mathrm{P}=0.01)$



Figure 3. Cumulative carbon $\mathrm{C}-\mathrm{CO}_{2}\left(\mathrm{mg} \mathrm{C} \mathrm{kg}^{-1}\right.$ soil) mineralization over 13 days of incubation of $0.4 \%$ glutamine, lysine, and glucose with and without $20 \%$ humic acid. Error bars are standard deviations from means of triplicate. No significant difference between treatments with same letter within the same day $(\mathrm{P}=0.01)$

\section{Enzymatic activities}

As shown in Figure 4a when vetch and wheat residue were applied alone the peak of $\beta$-glucosidase was achieved at day three; 378.17 and $377.7 \mu \mathrm{g} \mathrm{pNP} \mathrm{g}^{-1} \mathrm{~h}^{-1}$ for vetch and wheat treatments respectively. Throughout the incubation period the activity of $\beta$-glucosidase was higher for vetch than for wheat. When the soil was treated with humic acid, the initial activity of $\beta$-glucosidase was higher for vetch but at late stages of decomposition its activity was higher for wheat. Differences between treatments were not significant $(\mathrm{P}=0.01)$ at the end of the incubation.

As illustrated in Figure $4 \mathrm{~b}$, initially, vetch treatments (Vetch and Vetch+HA) showed higher levels of NAGase activity than wheat treatments (Wheat and Wheat $+\mathrm{HA}$ ). The activity of NAGase for wheat $+\mathrm{HA}$ treatment increased to reach its peak $\left(286.12 \mu \mathrm{g} \mathrm{pNP} \mathrm{g}^{-1} \mathrm{~h}^{-1}\right)$ at day 16 and its activity remained significantly $(\mathrm{P}=0.01)$ the greatest until the end of the incubation. On the other hand, when soil was amended with wheat alone, activity of NAGase didn't increase and stayed at low level throughout the period of incubation. 

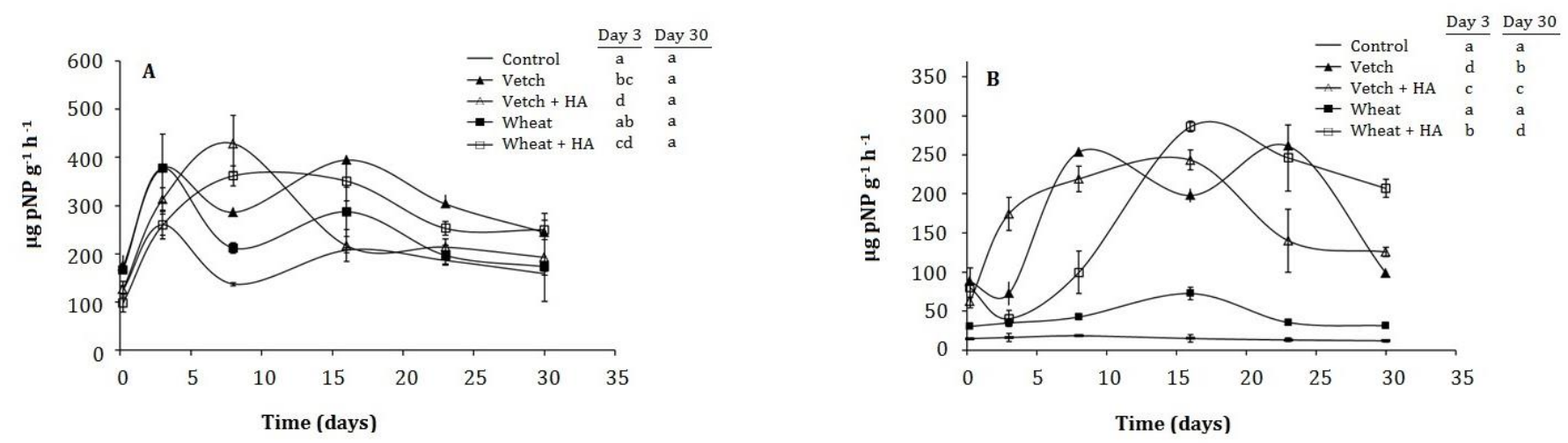

Figure 4. Time course changes of (a) $\beta$-glucosidase activity and (b) NAGase activity after incubating wheat and vetch residues with or without humic acid. Error bars are standard deviation from the means of duplicates. No significant difference between treatments with same letter within the same day $(\mathrm{P}=0.01)$

\section{Fungal and bacterial activities}

Applying plant residues either alone or in combination with humic acid resulted in an increase of SIR (Table 3 (A)), which can be used as an indicator of soil microbial biomass. Vetch residues caused the highest fungal respiration $\left(19.6 \mu \mathrm{g} \mathrm{CO}_{2} \mathrm{~g}^{-1}\right.$ soil h $\left.\mathrm{h}^{-1}\right)$, but it was reduced to $7 \mu \mathrm{g} \mathrm{CO}_{2} \mathrm{~g}^{-1} \mathrm{soil} \mathrm{h}^{-1}$ when humic acid was added. While bacterial respiration for vetch was nearly the same in the presence or absence of humic acid. Adding humic acid to wheat caused and increase in both fungal and bacterial respiration.

Table 3. Substrate induced respiration with selective inhibition. No significant difference between treatments with same letter.

\begin{tabular}{|c|c|c|c|c|c|c|c|c|c|c|c|}
\hline \multirow[b]{2}{*}{ Treatment } & \multicolumn{10}{|c|}{ Respiration $\left(\mu \mathrm{g} \mathrm{CO}_{2} \mathrm{~g}^{-1}\right.$ soil h$\left.^{-1}\right)$} & \multirow[b]{2}{*}{$\begin{array}{c}\mathrm{MBC}^{*} \\
\left(\mu \mathrm{g} \mathrm{g}^{-1}\right)\end{array}$} \\
\hline & & A & & B & & & $\mathrm{C}$ & & $\begin{array}{c}\text { Fungal } \\
\text { Respiration }\end{array}$ & $\begin{array}{c}\text { Bacterial } \\
\text { Respiration }\end{array}$ & \\
\hline Control & 13.96 & $\pm J .64(\mathrm{a})$ & 10.80 & \pm & $0.00(\mathrm{a})$ & 12.61 & \pm & $0.00(\mathrm{a})$ & 1.35 & 3.16 & 284.56 \\
\hline Vetch & 52.45 & $\pm J .95(d)$ & 32.86 & \pm & $1.91(d)$ & 47.72 & \pm & $1.27(d)$ & 4.73 & 19.6 & 1069.44 \\
\hline Vetch+ HA & 33.54 & $\pm 2.23(\mathrm{c})$ & 26.56 & \pm & $0.64(\mathrm{c})$ & 29.26 & \pm & $1.95(\mathrm{c})$ & 4.28 & 7.00 & 683.85 \\
\hline Wheat & 16.43 & $\pm J .32(\mathrm{a})$ & 13.06 & \pm & $0.64(\mathrm{a})$ & 15.31 & \pm & $1.27(\mathrm{a})$ & 1.12 & 3.37 & 335.10 \\
\hline Wheat+ HA & 24.76 & $\pm 0.64(\mathrm{~b})$ & 19.80 & \pm & $0.00(\mathrm{~b})$ & 22.07 & \pm & $0.00(\mathrm{~b})$ & 2.69 & 4.95 & 504.87 \\
\hline
\end{tabular}

*MBC $(\mu \mathrm{g} g-1)=(40.04 \times \mu \mathrm{l} \mathrm{CO2}$ g-1 Soil h-1) + 0.37

A:Total substrate induced respiration (respiration with no application of inhibitors)

B: Respiration after treating with cycloheximide

C: Respiration after treating with Sterptomycin sulfate

Fungal respiration: A-B

Bacterial respiration: A-C

\section{Discussion}

\section{Residue quality determines humic acid protection}

Different factions of plant derived organic molecules such as LMWOS, such as sugars and amino acids, can be released from plant residues into the soil. We hypothesize that interaction of these plant derived organic molecules with humic acid might have regulated the interaction of different residue with the applied humic acid.

The reduction in carbon mineralization from all LMWOS (Figure 3) can be explained by them being sorped to humic acid. Vieublé Gonod et al. (2006) showed that sorption of amino acids to soil solid phase retards their biodegradation. Several studies have shown that the sorption affinity of amino acids to soil minerals or organic material is controlled by properties of amino acids: basicity, hydrophobicity and molecular weight (Rothstein, 2010). In our study, among the LMWOS, the highest protection exerted by humic acid was for lysine and this effect lasted for the 13 days experimental period. This strong sorption can be explained by the strong electrostatic interaction through cation exchange of this positively charged hydrophilic compound (Liu and Lee, 2007). The humic acid used in this study has high CEC with 5.03 mmole/g of acidic functional groups (Table 2), which facilitate cation exchange. Sorption of glutamine and glucose (neutral hydrophilic soluble molecules) does not involve ion exchange and probably occurred through hydrogen bonding, which might explain their weaker interaction. Witthuhn et al. (2005) reported that covalently bound compounds are non- biodegradable, while weakly bound compounds may desorb and become available again for degradation. Piccolo et al. (1999) emphasized in the role of humic acid in protecting 2-decanol, a highly 
hydrophobic aliphatic alcohol, through hydrophobic- hydrophobic interactions. In our study the protection effect of humic acid to octanol (insoluble in water) was the least important due to the weaker hydrophobic interaction by the alkyl group compared to other forces. In this study, the adsorption affinity of the LMWOS to humic acid was in the order: soluble charged Lysine> soluble uncharged glutamine and glucose $>$ insoluble octanol.

Vetch is the most labile plant residue in this study. It contains higher amount of protein and soluble compounds and it has low lignin content (Baumann et al., 2009). Therefore, compared with wheat and oak, decomposition of vetch residue might have produced more amino acids and soluble compounds that might be preferentially sorped to the humic acid. Therefore, this protection effect lasted longer throughout the experimental period.

There was a recognizable higher mineralization for wheat $+\mathrm{HA}$, oak $+\mathrm{HA}$, glutamine $+\mathrm{HA}$ and glucose $+\mathrm{HA}$ compared with wheat, oak, glutamine and glucose alone at later stages of decomposition, this can be explained as 1 . Our humic acid is $90 \%$ pure and the remaining $10 \%$ might represent a source of bioavailable carbon, which can stimulate microbial growth and increases carbon mineralization in soils. This is also confirmed as applying humic acid alone increased carbon mineralization compared to the control 2. Priming effect, this will be explained in the next section.

\section{Humic acid- plant residue interaction and microbial community characteristics: Fungi the main actor}

The limited substrate availability when humic acid was applied with vetch caused a reduction in all microbial indices: $\beta$-glucosidase (Figure $4 \mathrm{a}$ ), fungal respiration, bacterial respiration and MBC (Table 3 ). The reduced activity of $\beta$-glucosidase can be explained as:

i) humic acid sequestered the cellobiose, therefore, limiting the activity of $\beta$-glucosidase,

ii) humic acid might adsorb $\beta$-glucosidase enzyme itself causing its limited activity. An experimental work by Lammirato et al. (2010) showed that adsorption of $\beta$-glucosidase on mineral surface retarded the hydrolysis of cellobiose.

In contrast to vetch, applying humic acid with wheat resulted in higher microbial indices Figure 4 and Table 3. This can be attributed to brimming effect. Wang et al. (2015) identified two theories of priming effect:

i) co-metabolism theory: applying high quality material (optimum $\mathrm{C}: \mathrm{N}$ and low lignin) will serve as an energy source to microorganisms to synthesize extracellular enzymes capable of degrading recalcitrant SOM

ii) N-limiting theory: adding fresh organic material with high C:N and high lignin simulates the degradation of SOM as a source of nutrients.

Our results agree with the first theory since the higher carbon mineralization for Wheat+ HA (Figure 2) was coupled with higher enzymatic activities (Figure 4). Fungi are the main actor of priming effect (Fontaine, 2011); therefore, we postulate that in the Wheat+HA treatment, humic acid was preferentially mineralized by fungi. This hypothesis is further confirmed as our results showed a higher fungal biomass, as indicated by a higher NAGase activity (Figure $4 \mathrm{~b}$ ) and a higher fungal respiration (Table 3) for the Wheat $+\mathrm{HA}$ treatment compared with the Wheat treatment. Six et al. (2006) reported that fungi have higher microbial growth efficiency (MGE) than bacteria. Ecosystems that promote fungal growth and activity are more efficient in sequestering carbon (Bailey et al., 2002).

Priming effect was not observed when humic acid was applied with vetch. This can be explained by the high soluble fraction and the high nutrient availability provided by vetch. Fontaine et al. (2011) reported that priming effect is low in high nutrient treatments. Fresh carbon source with high lability (high fraction of easily degradable compounds) and high nutrient availability will encourage fast-growing r-strategist microbes, which are not able to degrade recalcitrant material such as SOM. On the other hand, more polymerized carbon source will stimulate slow-growing K-strategist microbes, which are capable of comineralizing recalcitrant SOM with the fresh $\mathrm{C}$ source.

\section{Insights for carbon sequestration}

Our finding regarding the effect of applying humic acid with different plant residues on carbon sequestration can be explained as:

i) Applying plant residue with very low nutrient availability, such as oak, might result in the mineralization of recalcitrant organic materials such as humic acid as a source of nutrient $\left(2^{\text {nd }}\right.$ theory of brimming effect (Wang et al., 2015)). This will adversely affect carbon sequestration.

ii) Applying plant residue with medium level of nutrient availability, such as wheat, will enhance the synthesis of extracellular enzymes and the co-metabolism of humic acid (1 1 st theory of brimming effect 
(Wang et al., 2015)). This will cause a shift in the microbial community structure toward higher fungal population and positively affecting carbon sequestration.

iii) Applying plant residue with high nutrient availability, such as vetch, that has high mineralization rate. In this case humic acid will serve as a protecting agent of the plant residue against mineralization and hence enhancing carbon sequestration.

For enhancing carbon sequestration in agricultural soils, this study proposes two main protocols:

i) Applying humic acid to ecosystems that receive high amounts of easily degradable organic material as a mean of enhancing carbon sequestration through reducing carbon mineralization from these materials.

ii) Applying organic material with less degree of lability (such as wheat) in combination with recalcitrant organic material (such as humic acid) might be an efficient way to recover degraded soils and enhance carbon sequestration as a result of a better carbon retention, fungal activity and MGE.

\section{Conclusion}

This study proposes the application of humic acid as a way to reduce mineralization and enhance carbon sequestration. According to this study, the following conclusions could be withdrawn:

i) The protection exerted by humic acid against mineralization followed the lability of plant residue, where the degree of protection by humic acid was in the order vetch $>$ wheat $>0$ oak.

ii) The protection excreted by humic acid is probably related to the mechanism of interaction between different organic compounds and the humic acid. For example, the positively charged lysine form a strong electrostatic interaction with humic acid, while neutral compounds (such as glutamine) are weakly bounded to the humic acid.

iii) Compared to vetch, wheat residue had low carbon mineralization and a very low fungal activity throughout the incubation period. However, applying humic with this medium nutrient residue resulted in a priming effect and enhanced microbial structure toward a higher fungal population.

iv) Applying humic acid to areas that receive labile (high nutrient) residue is recommended as an innovative practice to reduce the emissions of $\mathrm{CO}_{2}$ to the atmosphere.

v) Applying humic acid in combination with less labile (medium nutrient) residue, such as wheat residue, is recommended as a way to recovering degraded soils.

vi) The results of this laboratory scale study must be further confirmed with long term field studies.

\section{References}

Bailey, V. L., Smith, J. L., Bolton, H., 2002. Fungal-to-bacterial ratios in soils investigated for enhanced C sequestration. Soil Biology and Biochemistry 34(7): 997-1007.

Baumann, K., Marschner, P., Smernik, R.J., Baldock, J.A., 2009. Residue chemistry and microbial community structure during decomposition of eucalypt, wheat and vetch residues. Soil Biology and Biochemistry 41(9): 1966-1975.

Bremner, J.M., 1996. Nitrogen-total. In: Methods of Soil Analysis. Part 3, Chemical Methods, Sparks, D.L., Page, A.L, Helmke, P.A., Loeppert, R.H., Soltanpour, P.N., Tabatabai, M.A., Johnston, C.T., Sumner, M.E. (Ed.). American Society of Agronomy, Soil Science Society of America. Madison, Wisconsin, USA. pp. 1085-1022.

Brookes, P.C., Joergenseu, R.G., 2005. Microbial biomass measurements by fumigation- extraction, In: Microbiological methods for assessing soil quality, Bloem, J., Hopkins, D.W., Benedetti, A., (Ed.). CBA, Wallingford, pp. $77-83$.

ESA, 2000. Carbon sequestration in soils. Ecological Society of America. Available at [Access date: 18.01.2020]: https://www.esa.org/esa/wp-content/uploads/2012/12/carbonsequestrationinsoils.pdf

Fontaine, S., Henault, C., Aamor, A., Bdioui, N., Bloor, J.M.G., Maire, V., Mary, B., Revaillot, S., Maron, P.A., 2011. Fungi mediate long term sequestration of carbon and nitrogen in soil through their priming effect. Soil Biology and Biochemistry 43(1): 86- 96.

Gee, G.W., Bauder, J.W., 1986. Particle-size Analysis. In: Methods of Soil Analysis. Part 2, Chemical and Microbiological Properties. Page, A.L., Miller, R.H., Keeney, D.R. (Eds.), 2nd Edition. Agronomy Monograph No. 9, American Society of Agronomy, Soil Science Society of America. Madison, Wisconsin, USA. pp. 383-411.

Jien, S.H., Wang, C.C., Lee, C.H., Lee, T.Y., 2015. Stabilization of organic matter by biochar application in compostamended soils with contrasting pH values and textures. Sustainability 7 (10): 13317-13333.

Lammirato, C., Miltner, A., Wick, L. Y., Kästner, M., 2010. Hydrolysis of cellobiose by $\beta$-glucosidase in the presence of soil minerals - Interactions at solid-liquid interfaces and effects on enzyme activity levels. Soil Biology and Biochemistry 42(12): 2203-2210.

Lin, Q., Brookes, P.C., 1999. An evaluation of the substrate-induced respiration method. Soil Biology and Biochemistry 31(14): 1969-1983.

Liu, Z., Lee, C., 2007. The role of organic matter in the sorption capacity of marine sediments. Marine Chemistry 105(34): 240-257. 
Mahmoodabadi, M., Heydarpour, E., 2014. Sequestration of organic carbon influenced by the application of straw residue and farmyard manure in two different soils. International Agrophysics 28(2): 169-176.

Melas, G.B., Ortiz, O., Alacañız, J.M., 2017. Can biochar protect labile organic matter against mineralization in soil?. Pedosphere 27(5): 822-831.

Moscatelli, M.C., Di Tizio, A., Marinari, S., Grego, S., 2007. Microbial indicators related to soil carbon in Mediterranean land use systems. Soil and Tillage Research 97(1): 51-59.

Nelson, D.W., Sommers, L.E., 1996. Total carbon and soil organic matter. In: Methods of Soil Analysis. Part 3, Chemical Methods. Sparks, D.L. Page, A.L., Helmke, P.A., Loeppert, R.H., Soltanpour, P.N., Tabatabai, M.A., Johnston, C.T., Sumner, M.E. (Eds.). American Society of Agronomy, Soil Science Society of America. Madison, Wisconsin, USA. pp. 961-1010.

Parham, J.A., Deng, S.P., 2000. Detection, quantification and characterization of $\beta$-glucosaminidase activity in soil. Soil Biology and Biochemistry 32(8-9): 1183-1190.

Piccolo, A., Spaccini, R., Haberhauer, G., Gerzabek, M. H., 1999. Increased sequestration of organic carbon in soil by hydrophobic protection. Naturwissenschaften 86(10): 496-499.

Piccolo, A., Spaccini, R., Nieder, R., Richter, J., 2004. Sequestration of a biologically labile organic carbon in soils by humified organic matter. Climatic Change 67(2-3): 329-343.

Pituello, C., Dal Ferro, N., Simonetti, G., Berti, A., Morari, F., 2016. Nano to macro pore structure changes induced by long-term residue management in three different soils. Agriculture, Ecosystems and Environment 217: 49-58.

Rasmussen, C., Southard, R. J., \& Horwath, W. R., 2006. Mineral control of organic carbon mineralization in a range of temperate conifer forest soils. Global Change Biology 12(5): 834-847.

Rothstein, D.E., 2010. Effects of amino-acid chemistry and soil properties on the behavior of free amino acids in acidic forest soils. Soil Biology and Biochemistry 42(10): 1743-1750.

Rovira, P., Vallejo, V.R., 2003. Physical protection and biochemical quality of organic matter in mediterranean calcareous forest soils: A density fractionation approach. Soil Biology and Biochemistry 35(2): 245-261.

Six, J., Frey, S.D., Thiet, R.K., Batten, K.M., 2006. Bacterial and Fungal Contributions to Carbon Sequestration in Agroecosystems. Soil Science Society of America Journal 70(2): 555-569.

Spaccini, R., Piccolo, A., Conte, P., Haberhauer, G., Gerzabek, M.H., 2002. Increased soil organic carbon sequestration through hydrophobic protection by humic substances. Soil Biology and Biochemistry 34(12): 1839-1851.

Tabatabai, M.A., 1994. Soil enzymes. In: Methods of Soil Analysis. Part 2, Microbiological and biochemical properties. Mickelson, S.H., Bighan, J.M. (Eds). American Society of Agronomy, Soil Science Society of America. Madison, Wisconsin, USA. pp. 775-826.

Thomas, G.W., 1996. Soil pH and soil acidity. In: Methods of Soil Analysis Part 2 Chemical and Microbiological Properties 2nd Edition, Page, A.L., et al. (Eds). American Society of Agronomy, Soil Science Society of America, Madison, Wisconsin, USA. pp. 475-490.

Tian, G., Chiu, C.Y., Franzluebbers, A.J., Oladeji, O.O., Granato, T.C., Cox, A.E., 2015. Biosolids amendment dramatically increases sequestration of crop residue-carbon in agricultural soils in western Illinois. Applied Soil Ecology 85: 86-93.

Vieublé Gonod, L., Jones, D.L., Chenu, C., 2006. Sorption regulates the fate of the amino acids lysine and leucine in soil aggregates. European Journal of Soil Science 57(3): 320-329.

Walter, H.G., 1986. Water content. In: Methods of Soil Analysis. Part 1, Physical and Mineralogical Methods, Klute, A. (Ed.). American Society of Agronomy, Soil Science Society of America. Madison, Wisconsin, USA. pp. 493 - 541.

Wang, H., Boutton, T.W., Xu, W., Hu, G., Jiang, P., Bai, E., 2015. Quality of fresh organic matter affects priming of soil organic matter and substrate utilization patterns of microbes. Scientific Reports 5: 10102.

Wang, X., Butterly, C.R., Baldock, J.A., Tang, C., 2017. Long-term stabilization of crop residues and soil organic carbon affected by residue quality and initial soil pH. Science of the Total Environment 587-588: 502-509.

Witthuhn, B., Klauth, P., Klumpp, E., Narres, H. D., Martinius, H., 2005. Sorption and biodegradation of 2,4dichlorophenol in the presence of organoclays. Applied Clay Science 28(1-4): 55-66. 